\title{
Productivity growth and R\&D expenditure in UK manufacturing firms
}

Citation for published version (APA):

Wakelin, K. (1997). Productivity growth and R\&D expenditure in UK manufacturing firms. MERIT, Maastricht Economic Research Institute on Innovation and Technology. MERIT Research Memoranda No. 012 https://doi.org/10.26481/umamer.1997012

Document status and date:

Published: 01/01/1997

DOI:

10.26481/umamer.1997012

Document Version:

Publisher's PDF, also known as Version of record

\section{Please check the document version of this publication:}

- A submitted manuscript is the version of the article upon submission and before peer-review. There can be important differences between the submitted version and the official published version of record.

People interested in the research are advised to contact the author for the final version of the publication, or visit the DOI to the publisher's website.

- The final author version and the galley proof are versions of the publication after peer review.

- The final published version features the final layout of the paper including the volume, issue and page numbers.

Link to publication

\footnotetext{
General rights rights.

- You may freely distribute the URL identifying the publication in the public portal. please follow below link for the End User Agreement:

www.umlib.nl/taverne-license

Take down policy

If you believe that this document breaches copyright please contact us at:

repository@maastrichtuniversity.nl

providing details and we will investigate your claim.
}

Copyright and moral rights for the publications made accessible in the public portal are retained by the authors and/or other copyright owners and it is a condition of accessing publications that users recognise and abide by the legal requirements associated with these

- Users may download and print one copy of any publication from the public portal for the purpose of private study or research.

- You may not further distribute the material or use it for any profit-making activity or commercial gain

If the publication is distributed under the terms of Article $25 \mathrm{fa}$ of the Dutch Copyright Act, indicated by the "Taverne" license above, 


\title{
Productivity Growth and R\&D Expenditure in UK Manufacturing firms
}

\author{
Katharine Wakelin \\ MERIT, P.O. Box 616, 6200 MD Maastricht, The Netherlands \\ Tel: +31 43 3883886, Fax: +31 43 3216518, Email: \\ K.wakelin@merit.unimaas.nl
}

October, 1997

\begin{abstract}
:
This paper analyses the relationship between productivity growth and R\&D expenditure at the firm level. A Cobb-Douglas function is estimated for 170 UK quoted firms including R\&D intensity as well as the capital to labour ratio. A positive and significant role is found for the firm's own R\&D expenditure in influencing productivity growth from 1988-1992; the relationship is no longer significant when sector fixed effects are included. To capture these sector effects, two spillover variables are included: the $R \& D$ expenditure of other firms in the same sector, and the weighted $R \& D$ expenditure of innovation-supplying industries. The former is found to play a large positive role in productivity growth, increasing it by around $1 \%$, while no significant role is found for the latter. The variation in technological opportunity across sectors appears to play an important role in the efficacy of R\&D expenditure.
\end{abstract}




\section{Introduction}

The investigation into the role of technology in productivity was originally prompted by the productivity slowdown noted in much of the industrialised world in the 1970s (Griliches, 1986). As research into the role of technological change in economic growth indicated that technological change is one of the key explanatory factors in productivity growth (Solow, 1957), the decline in productivity led to concerns that the level of technological change was diminishing. This in turn led to increased efforts to assess the importance of $R \& D$ expenditure, along with other indicators of technology, in influencing both the level of productivity and changes in productivity for different countries and different periods. Many of the ensuing studies examined the determinants of productivity at an aggregate country level, or by sector, although some research took the firm as the unit of analysis.

In keeping with the last studies this paper examines the relationship between $\mathrm{R} \& \mathrm{D}$ expenditure and growth in productivity at the firm level. This is the first firm-level study of its type for the UK. There are a number of advantages in considering the relationship from the perspective of the firm. First, a greater number of observations are generally available for firms than for sectors. Second, by considering the firm we can separate productivity improvements which occur as a result of the direct $R \& D$ efforts of the firm, from the technological improvements and advances which are general to the sector. Thus we can attempt to pinpoint the contribution of the firm's own technological resources to its productivity growth. One drawback of the firm approach is the quality of the R\&D data at the firm level which can be poor. While the evidence from firm-level studies for other countries confirms a positive role for $R \& D$ expenditure in explaining productivity growth, $R \& D$ expenditure has been of only limited explanatory power in explaining differences in productivity rates between firms, sectors and countries (Griliches and Mairesse, 1990).

Technology is treated in two different ways in the paper. First, the current commitment of resources to $\mathrm{R} \& \mathrm{D}$ expenditure is taken as one indicator of a 
firm's technological level. Second, the paper also aims to investigate if the relationship between productivity growth and $R \& D$ intensity varies according to the innovation history of the firm. In order to do so the firms are separated into two groups of firms: innovators and non-innovators, based on their past production of innovations. This classification aims to capture some aspects of technology which are not adequately reflected by $R \& D$ expenditure. The innovation history of a firm may proxy accumulated technological advantages, such as the attitude of the labour force and management towards innovation, and the general ability of the firm to implement change. There is some evidence (Malerba, Orsenigo and Peretto, 1997) that the ability to innovate is persistent and firm-specific, making innovative firms qualitatively different from non-innovating firms. To investigate this the estimates of productivity growth are made separately for innovating and non-innovating firms.

A Cobb-Douglas production function approach is used in this paper in common with many studies on productivity. The model relates growth in labour productivity to growth in the capital stock to labour ratio and R\&D intensity. The existence of constant returns to scale to labour and capital is explicitly tested for. The sample of 170 firms is made up of large firms quoted on the UK stock market, and as such does not represent a random sample. Data on $R \& D$ expenditure are available for all the firms in the sample, although the expenditure is frequently zero for some firms. While the results cannot be generalised to all firms in the economy, this sample of firms represents an important part of total manufacturing output (around 50\% in 1992).

As a comprehensive survey of the impact of $R \& D$ on productivity at the firm level already exists (Mairesse and Sassenou, 1991), this paper will concentrate on the practical problems raised in estimating productivity functions at the firm level and alternative ways of dealing with them. Section Two provides information on the sample and outlines the data used. Section Three sets out the relationship to be estimated and examines the results. The 
results are presented for all firms in the economy, and with innovating and non-innovating firms separated. Section Four of the paper looks for any variations in the relationship which may occur due to the sector in which the firm is located, and the role of spillovers of innovation from other firms in the economy on firm productivity. The last section gives some conclusions.

\section{The Sample and Data}

The sample of manufacturing firms used in this study can be divided into innovating and non-innovating firms, based on whether or not the firm was included in the SPRU survey of major innovations. The first group of firms termed innovating firms - was chosen from the firms included in the SPRU survey (a population of 1845 firms) ${ }^{1}$. The survey is designed to give exhaustive coverage of all firms which have had a major innovation in the UK from 1945 to 1983. The definition for the inclusion of an innovation in the survey is "the successful commercial introduction of new or improved products, processes or materials". The second group of firms was chosen randomly from Datastream, which has data on all quoted firms; those firms found to have had major innovations were rejected, leaving a sample of noninnovating firms. Only firms in the manufacturing sector were chosen for each sample; as $90 \%$ of innovations in the survey were exploited by manufacturing firms this selection covers the majority of innovations (Pavitt et al., 1987). Balance sheet data are available for all the firms from the same source (Datastream), along with the main sector they operate in; the firms are grouped in eighteen sectors based on the 1980 SIC classification ${ }^{2}$. Data were collected for a five-year period from 1988 to 1992. Out of this sample, firms with an increase in total sales of more than $80 \%$ in any one year were rejected as likely to have undergone a merger. These firms can be expected to have

\footnotetext{
${ }^{1}$ For more information on the survey see Pavitt et al. (1987) and Robson et al. (1987). The information in the survey has been used before in sector-level productivity studies such as Geroski (1991) and Sterlacchini (1989).

${ }^{2}$ Only one sector is given for each firm, thus firms with diversified interests will be classified in the sector which constitutes their main line of business. As a result quite general 2-digit sector divisions are used to categorise the firms in order to minimise this problem. The use of plant-level rather than firm-level as in Lichtenberg and Siegel (1991) avoids this problem and allows for a more exact classification.
} 
experienced productivity changes due to the merger alone, and are thus likely to bias the sample.

One drawback of the classification of firms into innovating and noninnovating groups is that it is based on a period finishing five years before the period covered by the data set. As a result, some firms may have innovated in the intervening period and thus be miss-classified as non-innovators. As the survey has not been updated to cover the period in question, this risk is unavoidable; we assume that it would affect only a few firms at most as the criteria for being included in the survey are very strict. The resulting sample of 170 firms is evenly split between innovating ( 85 firms) and non-innovating firms (85 firms).

The $R \& D$ data available from Datastream are of mixed quality. A number of firms have registered zero $R \& D$ expenditure over the period and this may not be an accurate reflection of their actual expenditure. In order to contrast the $R \& D$ expenditure registered by the firms in the sample with the national statistics for R\&D expenditure at the sector level, the average R\&D intensity ( $R \& D$ expenditure over total sales) is calculated over the five year period from national sectoral data and from the sample; the standard deviation is given in brackets ${ }^{3}$. The firms are grouped into ten rather than eighteen sectors due to the small numbers of firms in some sectors. The R\&D intensities are given in Table 1. As the sample consists of large quoted firms we would expect the average $R \& D$ intensity of the sample to be higher than that of the sector as a whole; however, it is clear from the table that this is the case only in some sectors. Overall, the mean firm $R \& D$ intensity over the sample is $1.6 \%$, while the mean across the ten sectors is $2.6 \%$ (both means are not weighted by size). This difference appears to be present in both the innovating and non-innovating firm samples ${ }^{4}$.

\footnotetext{
${ }^{3}$ For definitions of the variables, the sectors and the sources see the Appendix.

4 As no systematic variation is observed over the two groups, the under-reporting should not alter any differences found between the groups.
} 
On a sector basis, the chemical and man-made products sector and the electronic and electrical machinery sectors, show a lower R\&D intensity for the sample firms than for the sector as a whole. The office and data machinery sector has a considerably lower R\&D intensity, this may be due to the low number of firms representing this sector (only 9 in the case of office and data machinery). Nevertheless the comparison highlights some weakness in the R\&D expenditure data: firms have clearly been under-reporting $R \& D$ expenditure in their annual accounts.

\section{Table 1: Total factor productivity growth and R\&D intensity 1988-1992}

\begin{tabular}{|c|c|c|c|c|}
\hline Sector & $\mathbf{N}$ & TFP growth & $\begin{array}{l}\text { Sample R\&D } \\
\text { intensity }\end{array}$ & $\begin{array}{l}\text { Sector R\&D } \\
\text { intensity }\end{array}$ \\
\hline All firms & 170 & $\begin{array}{l}-0.020 \\
(0.080)\end{array}$ & $\begin{array}{l}0.016 \\
(0.030)\end{array}$ & 0.026 \\
\hline Innovators & 85 & $\begin{array}{l}-0.014 \\
(0.070)\end{array}$ & $\begin{array}{l}0.023 \\
(0.036)\end{array}$ & 0.032 \\
\hline Non-innovators & 85 & $\begin{array}{l}-0.027 \\
(0.090)\end{array}$ & $\begin{array}{l}0.008 \\
(0.020)\end{array}$ & 0.020 \\
\hline 1. Metal manufacturing and goods & 10 & $\begin{array}{l}-0.030 \\
(0.097)\end{array}$ & $\begin{array}{l}0.005 \\
(0.006)\end{array}$ & 0.004 \\
\hline 2. Non-metallic manufacturing & 12 & $\begin{array}{l}-0.048 \\
(0.077)\end{array}$ & $\begin{array}{l}0.006 \\
(0.009)\end{array}$ & 0.003 \\
\hline 3. Chemical and man-made products & 17 & $\begin{array}{l}0.014 \\
(0.056)\end{array}$ & $\begin{array}{l}0.030 \\
(0.041)\end{array}$ & 0.054 \\
\hline 4. Mechanical Engineering & 36 & $\begin{array}{l}-0.049 \\
(0.085)\end{array}$ & $\begin{array}{c}0.009 \\
(0.013)\end{array}$ & 0.009 \\
\hline 5. Office and Data machinery & 9 & $\begin{array}{l}0.074 \\
(0.122)\end{array}$ & $\begin{array}{l}0.008 \\
(0.015)\end{array}$ & 0.070 \\
\hline 6. Electrical and electronic machinery & 22 & $\begin{array}{l}0.016 \\
(0.066)\end{array}$ & $\begin{array}{l}0.040 \\
(0.049)\end{array}$ & 0.070 \\
\hline 7. Transport & 11 & $\begin{array}{l}0.003 \\
(0.064)\end{array}$ & $\begin{array}{l}0.040 \\
(0.037)\end{array}$ & 0.042 \\
\hline 8. Instruments & 5 & $\begin{array}{l}-0.084 \\
(0.001)\end{array}$ & $\begin{array}{l}0.044 \\
(0.056)\end{array}$ & 0.023 \\
\hline $\begin{array}{l}\text { 9. Food, textiles, leather, footwear, } \\
\text { timber, paper and printing }\end{array}$ & 31 & $\begin{array}{l}-0.044 \\
(0.062)\end{array}$ & $\begin{array}{c}0.002 \\
(0.003)\end{array}$ & 0.002 \\
\hline $\begin{array}{l}\text { 10. Rubber, plastics, other } \\
\text { manufacturing }\end{array}$ & 16 & $\begin{array}{l}-0.001 \\
(0.044)\end{array}$ & $\begin{array}{c}0.002 \\
(0.003)\end{array}$ & 0.005 \\
\hline
\end{tabular}

The table also gives averages for total factor productivity (TFP) growth for the whole sample, each group of firms, and by sector ${ }^{5}$. The total firm average shows a fall in TFP over the period considered; this fall was almost twice as

\footnotetext{
${ }^{5}$ In calculating TFP the share of labour is given by total employee remuneration over total sales averaged over two years, and the share of capital is taken as 1 less the share of labour, i.e. constant returns to scale are assumed. TFP growth is taken as an average over the four-year period from 1989 to 1992.
} 
large for the non-innovating firms as for the innovating firms. The difference between innovating and non-innovating firms indicates that the former may have characteristics which partly protect them from declining productivity. The TFP statistics by sector show six sectors experienced declining TFP, and four positive growth. The largest growth was experienced in the office and data machinery sector, and the largest fall in the instruments sector. This period was clearly one of recession, in which the rising productivity experienced in the 1980s stagnated or declined. This is confirmed by evidence at the sector level of a similar decline in aggregate manufacturing productivity from 1989 onwards (Lansbury and Mayes, 1996).

In order to calculate productivity, data were collected on employment, capital and output for each firm. Employment is defined as the firm's number of employees (L); the number of hours worked per employee is not available. The use of number of employees neglects any change in hours worked over the period, such as a reduction in overtime, which may have an impact on productivity. However, data limitations leave no alternative. For the capital variable, total fixed gross assets are used, and deflated over time using the national investment deflator to give real capital $(\mathrm{K})$. As with the labour variable, the capital variable cannot be corrected for the level of capital utilisation over the period as the data are not available. Capital utilisation may fall during a recession lowering productivity ${ }^{6}$. The ideal choice for the output variable would be value added, however, as this is also not available it is substituted with total sales deflated by a sector-level producer price index to give real total sales $(\mathrm{Q})^{7}$. Sales and capital were both divided by employment to give per capita values, and the growth rate for each variable was taken as the average of the log of change in growth for each of the four year periods between 1988 and 1992.

\footnotetext{
6 As has been noted elsewhere (Odagiri and Iwata, 1986) the impact of changes in hours worked and capital utilisation is considerable over time. However, in a cross-section the impact of both these factors is unlikely to affect the results unless they vary systematically across firms. Inter-sector differences can be captured by the use of sector dummy variables, and we have no reason to assume that capital and labour utilisation would vary systematically across firms in the same sector.

${ }^{7}$ There is some evidence that the use of real sales rather than value-added may alter the results, in particular for the capital variable and for the period of the two oil shocks. See Mairesse and Sassenou (1991) for details.
} 
Table Two gives the average growth rates for sales per employee, the capital to labour ratioi, and the number of employees, as well as the employment level in 1992 to give an indicator of firm size. The variables are shown for all firms, innovating and non-innovating firms grouped together, and on a sector basis.

\section{Table 2: Descriptive statistics: means (and standard deviations)}

\begin{tabular}{lllll}
\hline & & \multicolumn{3}{c}{ Average growth rates 1988-1992 } \\
\cline { 3 - 5 } \multicolumn{1}{c}{ Sector } & $\begin{array}{l}\text { Employment } \\
\mathbf{1 9 9 2}\end{array}$ & $\begin{array}{l}\text { Sales per } \\
\text { employee }\end{array}$ & $\begin{array}{l}\text { Capital per } \\
\text { employee }\end{array}$ & $\begin{array}{l}\text { Number of } \\
\text { employees }\end{array}$ \\
\hline All firms & 15,874 & 0.017 & 0.050 & -0.010 \\
& $(29,722)$ & $(0.070)$ & $(0.101)$ & $(0.117)$ \\
Innovators & 21,702 & 0.026 & 0.051 & -0.016 \\
& $(29,328)$ & $(0.059)$ & $(0.081)$ & $(0.112)$ \\
Non-innovators & 10,694 & 0.008 & 0.048 & -0.004 \\
& $(29,332)$ & $(0.081)$ & $(0.116)$ & $(0.121)$ \\
1. Metal manufacturing and goods & 10,787 & -0.005 & 0.038 & -0.028 \\
& $(15,020)$ & $(0.045)$ & $(0.144$ & $(0.131)$ \\
2. Non-metallic manufacturing & 15,172 & -0.031 & 0.030 & 0.054 \\
& $(18,578)$ & $(0.070)$ & $(0.055)$ & $(0.088)$ \\
3. Chemical and man-made products & 31,720 & 0.048 & 0.043 & -0.033 \\
& $(43,770)$ & $(0.059)$ & $(0.063)$ & $(0.096)$ \\
4. Mechanical Engineering & 6,949 & 0.014 & 0.082 & -0.012 \\
& $(9,958)$ & $(0.081)$ & $(0.136)$ & $(0.136)$ \\
5. Office and Data machinery & 2,379 & 0.091 & 0.022 & -0.023 \\
& $(3,605)$ & $(0.072)$ & $(0.087)$ & $(0.164)$ \\
6. Electrical and electronic machinery & 16,855 & 0.038 & 0.027 & -0.026 \\
& $(30,216)$ & $(0.055)$ & $(0.086)$ & $(0.138)$ \\
7. Transport & 40,351 & 0.038 & 0.049 & 0.017 \\
& $(39,051)$ & $(0.083)$ & $(0.076)$ & $(0.069)$ \\
8. Instruments & 6,202 & -0.009 & 0.097 & -0.030 \\
& $(7,600)$ & $(0.022)$ & $(0.018)$ & $(0.024)$ \\
9. Food, textiles, leather, paper \& & 22,445 & -0.012 & 0.055 & -0.003 \\
printing, footwear, timber & $(42,027)$ & $(0.065)$ & $(0.097)$ & $(0.110)$ \\
10. Rubber, plastics, other & 1,379 & 0.017 & 0.009 & -0.027 \\
manufacturing & $(2,102)$ & $(0.036)$ & $(0.054)$ & $(0.090)$ \\
\hline
\end{tabular}

The average employment of over 15,000 people per firm in 1992 indicates the size of this sample of firms. Innovating firms are also noticeably larger than non-innovating firms (twice as large) and there is considerable variation in average firm size per sector. For all the firms considered together deflated sales per employee rose by $1.7 \%$; contributing to this rise was a fall in employment of $1.0 \%$. The deflated capital to labour ratio also rose, by $5.0 \%$ over the period. These movements were greater for the innovating firms than 
the non-innovating. The former group of firms showed a larger increase in labour productivity, $2.6 \%$ against an increase of only $0.8 \%$ for the latter. This was partly explained by a greater decrease in employment for the innovating firms: employment fell four times more in the innovating firms than the noninnovating firms. The capital to labour ratio rose by approximately the same amount for both groups of firms. Innovating firms thus experienced faster growing labour productivity, and larger falls in employment than noninnovating firms.

Examining the relationship at the sector level shows a great deal of diversity among sectors. Reflecting the results for TFP in Table 1, labour productivity rose in six of the ten sectors, and fell in the other four. Only two sectors non-metallic manufacturing and the transport sector - showed rises in employment. The capital to labour variable showed less variation by sector than employment or sales, but all the variables exhibit considerable heterogeneity across different sectors and firms. In order to examine the relationship in more detail a model of productivity is estimated in the next section.

\section{R\&D Intensity and Productivity Growth}

The model used to estimate productivity growth is a version of the CobbDouglas production function in its growth rate form. The production function includes the standard factors of capital and labour as well as the additional factor of knowledge capital. The objective is to attribute the rate of increase in productivity to increases in its inputs. From the Cobb-Douglas function productivity could be measured in two main ways: as total factor productivity, i.e. the productivity increase not attributable to increases in inputs, or as labour productivity. The latter will be preferred here, and the restrictive assumption necessary in considering labour productivity - constant returns to scale - will be tested ${ }^{8}$.

\footnotetext{
${ }^{8}$ Estimates were also made using TFP rather than labour productivity; the results are very similar.
} 
The inclusion of knowledge capital in the production function is to account for increases in productivity which occur due to technological improvements at the firm level. A number of proxies can be used for knowledge capital, including stocks of $\mathrm{R} \& \mathrm{D}$ expenditure, patent counts and data on actual innovations. $R \& D$ expenditure is the most common choice. One problem with including $\mathrm{R} \& \mathrm{D}$ expenditure with capital and labour is that some double counting occurs as R\&D expenditure is embedded in both the other factors: capital equipment and researchers in R\&D laboratories will be included in the capital and labour variables respectively. As the necessary data are not available double counting cannot be corrected for here. The result is likely to be a downward bias in the estimates of the R\&D coefficient. The production function is given by:

$Q_{i t}=A e^{\lambda t} K_{i t}^{\alpha} L_{i t}^{\beta} R_{i t}^{\gamma} \mu^{\varepsilon_{i t}}$

where $\mathrm{Q}$ is a measure of output for firm $i$ at time $t$ (in this case total sales), $\mathrm{K}$ is a measure of physical capital, $\mathrm{L}$ of labour employed, and $\mathrm{R}$ of knowledge capital. A is a constant and $\alpha, \beta$ and $\gamma$ are the elasticities of output with respect to physical capital, labour and knowledge capital. $\lambda$ represents disembodied technical change; $\mu$ is an error term which captures the effects of unknown factors. By taking logarithms of the variables and first differencing the relationship can be expressed as a linear one in terms of labour productivity:

$(q-l)_{\mathrm{it}}=\lambda+\alpha(k-l)_{\mathrm{it}}+\gamma r_{\mathrm{it}}+\theta l_{\mathrm{it}}+v_{\mathrm{it}}$

where the variables in lower case are the rates of growth of output (q), labour (l), physical capital (k), and knowledge capital (r). Due to the rearrangement of the productivity relationship into labour productivity:

$$
\theta=\alpha+\beta-1
$$

which is the constant returns to scale coefficient. If this is equal to zero then constant returns to scale cannot be rejected; a coefficient significantly different from zero indicates that constant returns to scale for labour and 
capital can be rejected. As R\&D expenditure data are not available for enough years to calculate the stock of knowledge the function can be transformed by taking the rate of return to $R \& D$ as the parameter of interest rather than the elasticity ${ }^{9}$. As the rate of return $\rho$ is related to the elasticity $\gamma$ by $\gamma=\rho(R / Q)$ and the first difference of $\mathrm{R}$ is $(\Delta \mathrm{R} / \mathrm{R})$ substituting allows us to include the term $\rho(\Delta R / Q)$. By assuming no depreciation in $R \& D$ the change in the knowledge capital $\Delta \mathrm{R}$ is equal to present $\mathrm{R} \& \mathrm{D}$ expenditure $\mathrm{RD}$. Therefore the relationship to be estimated is given by:

$(q-l)_{\mathrm{it}}=\lambda+\alpha(k-l)_{\mathrm{it}}+\rho(\mathrm{RD} / \mathrm{Q})_{\mathrm{it}}+\theta l_{\mathrm{it}}+v_{\mathrm{it}}$

where $R \& D$ intensity is the average of $R \& D$ expenditure over total sales for each year. Some studies use only R\&D expenditure from the first years of the period under consideration in order to allow for the lagged effects of R\&D. However, as pointed out elsewhere (Scherer, 1982), R\&D intensity is relatively stable over time so the timing of the variable seems to have little effect in practise. Using the whole period is preferred here in order to have as many years possible in calculating average $R \& D$ intensity.

A number of different equations is estimated. Initially the most simple model including only the capital to labour ratio is included (Regression 1). Secondly, the R\&D intensity term is added (Regression 2); and thirdly the additional labour term is included to check for constant returns to scale (Regression 3). The same estimates are then repeated with 10 sector dummy variables. The results from all of the estimates are given in Table Three. The model is estimated for all the firms together, and with innovating and non-innovating firms separated, as discussed in Section Two.

\section{Table 3: An analysis of labour productivity growth in manufacturing in the UK, 1988-1992.}

\begin{tabular}{lllllllll}
\hline Regression & $\mathrm{k} / \mathrm{l}$ & $\mathbf{l}$ & $\mathrm{RD} / \mathrm{Q}$ & $\mathbf{R}^{2}$ & $\mathrm{k} / \mathrm{l}$ & $\mathrm{l}$ & $\mathbf{R D} / \mathbf{Q}$ & $\mathbf{R}^{2}$ \\
\hline
\end{tabular}

\footnotetext{
${ }^{9}$ The relationship is frequently estimated in this form giving an estimate of research elasticity; see for instance Cuneo and Mairesse (1984) and Griliches (1986).
} 
Without sector dummy variables

\begin{tabular}{lll} 
1. All Firms & $\begin{array}{l}0.29 * * * \\
(0.06)\end{array}$ \\
& $0.21 * *$ \\
Innovators & $\begin{array}{l}0.09) \\
\text { Non-innovators }\end{array}$ & $0.32 * * *$ \\
& $(0.09)$ & \\
2. All Firms & $0.29 * * *$ \\
& $(0.06)$ & \\
Innovators & $0.22 * *$ & \\
& $(0.09)$ & \\
Non-innovators & $0.33 * * *$ & \\
& $(0.08)$ & \\
3. All Firms & $0.23 * * *$ & $-0.11^{*}$ \\
& $(0.07)$ & $(0.06)$ \\
Innovators & 0.07 & $-0.21 * * *$ \\
& $(0.11)$ & $(0.08)$ \\
Non-innovators & $0.33 * * *$ & -0.02 \\
& $(0.09)$ & $(0.09)$ \\
\hline
\end{tabular}

\begin{tabular}{|c|c|c|c|c|c|}
\hline & \multicolumn{5}{|c|}{ With sector dummy variables } \\
\hline & 0.17 & $\begin{array}{l}0.32 * * * \\
(0.06)\end{array}$ & & & 0.36 \\
\hline & 0.09 & $\begin{array}{l}0.21 * * \\
(0.09)\end{array}$ & & & 0.28 \\
\hline & 0.22 & $\begin{array}{l}0.44 * * * \\
(0.08)\end{array}$ & & & 0.55 \\
\hline $\begin{array}{l}0.35 * \\
(019)\end{array}$ & 0.19 & $\begin{array}{l}0.32 * * * * \\
(0.06)\end{array}$ & & $\begin{array}{l}0.16 \\
(0.21)\end{array}$ & 0.37 \\
\hline $\begin{array}{l}0.18 \\
(0.19)\end{array}$ & 0.10 & $\begin{array}{l}0.21 * * \\
(0.09)\end{array}$ & & $\begin{array}{l}0.01 \\
(0.23)\end{array}$ & 0.28 \\
\hline $\begin{array}{l}1.83 * * \\
(0.91)\end{array}$ & 0.28 & $\begin{array}{l}0.44 * * * \\
(0.08)\end{array}$ & & $\begin{array}{l}0.12 \\
(0.95)\end{array}$ & 0.55 \\
\hline $\begin{array}{l}0.32 * \\
(0.19)\end{array}$ & 0.22 & $\begin{array}{l}0.28 * * * \\
(0.07)\end{array}$ & $\begin{array}{l}-0.07 \\
(0.06)\end{array}$ & $\begin{array}{l}0.15 \\
(0.21)\end{array}$ & 0.38 \\
\hline $\begin{array}{l}0.16 \\
(0.18)\end{array}$ & 0.22 & $\begin{array}{l}0.08 \\
(0.11)\end{array}$ & $\begin{array}{l}-0.19 * * \\
(0.08)\end{array}$ & $\begin{array}{l}0.05 \\
(0.22)\end{array}$ & 0.36 \\
\hline $\begin{array}{l}1.79 * * \\
(0.93)\end{array}$ & 0.28 & $\begin{array}{l}0.43 * * * \\
(0.09)\end{array}$ & $\begin{array}{l}-0.01 \\
(0.08)\end{array}$ & $\begin{array}{l}0.08 \\
(0.99)\end{array}$ & 0.55 \\
\hline
\end{tabular}

The results for the whole sample show a significant role for $R \& D$ intensity with $\mathrm{R} \& \mathrm{D}$ contributing $0.35 \%$ to productivity growth. Although results can be difficult to compare due to the use of different data and assumptions, this result is consistent with similar estimates for Japan and the US (Griliches and Mairesse, 1990) and France (Griliches and Mairesse, 1983), and considerably higher than that found for Belgium (Fecher, 1989). When the sample is split, it appears that $R \& D$ intensity is a significant factor in productivity growth only for the non-innovating firms, for which it is contributing a very high $1.83 \%$. It should be noted that fewer non-innovative firms have R\&D than innovative firms, however, for those that do it appears to be contributing considerably to productivity growth.

The coefficient on the R\&D intensity variable is significantly lowered when sector dummy variables are included, to the point of no longer being significant even for the innovating firms. This result is also consistent with other studies such as Odagiri and Iwata (1986) for Japan and Griliches and Mairesse (1983) for France and the US which have found coefficients to be reduced by as much as half through the inclusion of sector dummies. The results here show a very large reduction in the size of the coefficient, particularly for the non-innovative firms. 
The inclusion of industry effects is to account for factors which may vary by industry and which have been omitted from the model. In the present model there are no variables which indicate the different economic conditions experienced in each industry. As shown by the descriptive statistics presented in Section Two, there is considerable heterogeneity among sectors. By including the sector dummies the estimates are reflecting the role of the explanatory variables in explaining productivity growth for firms within each sector rather than for firms in different industries. Odagiri and Iwata (1986) find a strong role for sector dummies, and conclude that this indicates the importance of inter-industry differences in the rate of exogenous technical progress.

However, the role of the industry variables in reducing bias has been called into question (Mairesse and Cuneo, 1985, Mairesse and Sassenou, 1991). They argue that in order to pick up sector specific effects it may be more appropriate to introduce variables which have been omitted - such as the level of technological opportunity in the sector, and the presence of inter-sector spillovers - instead of the dummy variables. This approach will be implemented in the next section when both the R\&D within the sector and spillovers between sectors are included in the model.

To turn to the other results, the coefficient on the capital to labour ratio also varies across the two groups of innovating and non-innovating firms. Noninnovating firms have a higher coefficient in general (0.44 against 0.21 for the innovators), indicating that an increase in teh capital to labour ratio has a greater effect on productivity growth for non-innovating firms than innovating firms, although both coefficients are significant. The results for the capital to labour ratio for all the firms are not altered by the inclusion of the sector dummies, although the coefficient for the non-innovating firms alone is raised. In general the coefficients are similar for those found for other countries in different studies with a coefficient a little over $0.2 \%$ found for all the firms together. 
The coefficient on the labour variable, which is included to check for constant returns to scale, is significantly different from zero for all firms (when industry dummies are not included); when the sample is split this result is found for the innovating firms alone. Diminishing returns are found in both these cases i.e. the sign on the variable is negative. A similar model for the US and Japan Griliches and Mairesse (1990) also found evidence for the US of diminishing returns at a comparable level with the results found here. The results for Japan showed even larger diminishing returns $(0.24$ when sector dummies were included). The large diminishing returns found for the innovating firms are not reflected in their overall productivity experience (which is better than that of the non-innovators) presumably due to the larger decrease in employment experienced by those firms.

Constant returns to scale are not rejected for the non-innovating firms alone. When the diminishing returns for innovative firms are taken account of in Regression 3, the coefficient on the capital to labour ratio drops dramatically from 0.21 to 0.08 . No such effect is found for the non-innovative firms. We would expect the coefficient to decline as any increase in the capital to labour ratio has a more limited effect on productivity if there are diminishing returns; nevertheless this is a large fall in the coefficient. One explanation for the large size of the diminishing returns found for the innovating firms, but not for the non-innovating, may be the larger average size of the former group. As Table Two shows, innovating firms in this sample are on average twice the size of non-innovating firms in terms of employment. These larger firms may have exceeded optimal scale, although it is unclear why firms would chose this larger size. An alternative explanation is that they are located in sectors which have experienced diminishing returns to scale. The sector dimension will be investigated in the next section.

Overall, the three factors of capital, labour and $R \& D$ explain a higher percentage of the variation in the growth of labour productivity for the noninnovating firms than for the innovating firms. It appears that for the innovating firms there are additional factors which have not been included in 
the model but which are important in explaining productivity growth. The more positive record of innovating firms in productivity growth noted in the earlier section cannot be explained by the factors included in this model. In order to investigate sector-specific factors which may be influencing the results, the next section looks at the role of $\mathrm{R} \& \mathrm{D}$ from other firms in productivity growth, and how the productivity growth relationship varies by sector.

\section{Spillovers and Sector Variation}

There is a lively debate on the role of spillovers of innovations in the economy and their effect on economic growth. The attention given to attempts to quantify the role of technology spillovers has increased considerably since their recent inclusion in theoretical growth models (for instance, Romer, 1986, and Grossman and Helpman, 1991). It is the characteristics of technological change - namely non-rivalry in the use of innovations and difficulties in appropriating new technology - which have led to its association with spillovers. One seminal contribution, Griliches (1979), suggests the existence of two different types of economic spillovers: rent spillovers and knowledge spillovers. The former are associated with difficulties in capturing the full economic benefits of an innovation via its price, while the latter deal with flows of knowledge which are not part of an economic transaction. Rent spillovers occur because the producer of an innovation does not charge a price which fully reflects the benefits of the innovation to the innovation user. As a result productivity improvements accrue to the user firm from the $R \& D$ expenditure of the producer firm.

Knowledge spillovers relate to the production of knowledge which has public-good characteristics limiting the ability of the firm to stop another person, or firm, exploiting it. Not all knowledge falls into this category; some knowledge may be private and easily appropriated by the firm. Knowledge transmitted through scientific journals, and via the product itself (accessible through reverse engineering), and the movement of skilled personnel between 
firms, falls into this category. Thus a firm may use knowledge originating in another firm without paying the full price for its benefits.

There are surveys which assess the large literature built up around the estimation of spillovers (Nadiri, 1993, Griliches, 1992), and which generally conclude that while there is evidence for a role of spillovers, estimates of their importance vary greatly across studies. There is also a large amount of variety in the proxies used to measure spillovers. $R \& D$ expenditure, patent information and innovation surveys have all been used to approximate the knowledge capital stock of other firms. In addition, different estimates of the technological distance of firms from each other, and of sectors, have been used to weight this technology stock (Jaffe, 1986) ${ }^{10}$. Two different variables are included in this paper to represent $R \& D$ undertaken by other firms in the economy; they are outlined below.

The first is the $R \& D$ expenditure of firms in the same sector as the firm (excluding the firm's own R\&D) which is included to capture the technological level of the sector in which the firm is located. While not all R\&D conducted by other firms in the same sector will necessarily spill over to the firm, the level of R\&D activity in the sector gives an indication of the level of technological opportunity in the sector, and the size of the available pool of technological knowledge. The $R \& D$ expenditure at the sector level is divided by total sales in the sector to give sector R\&D intensity (SECRD/ $\mathrm{Q}_{\mathrm{s}}$ ); no weighting is applied.

A second variable is calculated to account for spillovers of $R \& D$ expenditure from other sectors in the economy. It is necessary to apply a weighting system to this $R \& D$ expenditure as not all sectors in the economy will have the same technological distance from each firm. In this case a use and production of innovations matrix has been created from the SPRU survey of innovations. This gives a map of the production and use of innovations among sectors ${ }^{11}$.

\footnotetext{
${ }^{10}$ For a useful review of measurement methods see Los (1997).

${ }^{11}$ The eighteen-sector classification is used rather than the ten-fold one used earlier in the paper in order to have greater precision in estimating the spillovers.
} 
The sector in which the innovation is produced is known, as is the sector in which the innovation is first used; together these are used to create a matrix in which the off-diagonal elements give the flows of innovations among sectors $^{12}$. The survey is a unique source of information on innovation diffusion in the UK, however, it has some limitations. Only the place of first use of the innovation is known so diffusion of the innovation after the first user is not captured. As a result, the matrix may understate the actual diffusion of each innovation which takes place across sectors. In addition, the survey includes only major innovations rather than small or incremental innovations; this omission will also have the effect of underestimating the level of innovation. One example of a large innovation flow from the survey is from the mechanical engineering sector to the chemical and man-made goods sector; another is from the electrical and electronic sector to the instruments sector. The diagonal elements show the number of innovations used in the same sector they were produced in. This value turns out to be highly correlated with each sector's R\&D expenditure and is not used in the estimates. The matrix of off-diagonal elements which shows the flow of innovations to other sectors is then used to weight the average $R \& D$ of different sectors from 1988 to 1992 . The weighted R\&D gives the spillovers of R\&D to sector $s$ in which the firm is located; this is then divided by the total sales in sector $s$ in order to give a spillover intensity variable (SPILL/Q ${ }_{s}$ ). Only those innovations both used and produced within manufacturing are considered $^{13}$.

The second spillover proxy used in this paper is certainly most effective in capturing rent spillovers, based as it is on producer-user relationships. Neither proxy directly measures knowledge spillovers, although using the $R \& D$ expenditure of other firms in the sector may reflect knowledge availability in

\footnotetext{
12 The entire period of the survey $1945-1983$ is used to make the matrix. However, using the last five years of the survey alone makes little difference to the pattern found (Wakelin, 1997); the pattern of use and production of innovations is very stable over time.

${ }^{13}$ This does not include innovations which originate outside manufacturing e.g. in R\&D services, but are used in manufacturing; however, these are a very small proportion of the total. A large number of innovations are produced in manufacturing and used in other sectors of the economy, and this flow of innovations is also not included in the classification, as this paper concentrates on spillovers within manufacturing.
} 
the sector. Initially, the first spillover intensity variable is added to the estimation alone and then both are added together. The firm $R \& D$ intensity variable is not included as it is collinear with sector $R \& D$, creating difficulties in separating the effects of the two variables. The results are given in Table 4 for the two sets of regressions. Once again the firms are also separated into the two groups of innovating and non-innovating firms.

The results show a goodness of fit that is comparable to the model in Table Three including dummy variables. It appears that including a sector-level variable (in this case sector R\&D intensity) improves the amount of productivity growth explained by the model by around $14 \%$. The results for the capital to labour variable, and the constant returns variable are also essentially the same as in the earlier model. This similarity in results indicates that the sector dummies may have been acting as a proxy for the $R \& D$ intensity at the sector level, which in turn indicates the level of technological opportunity in the sector. As with the earlier model the coefficient on the capital to labour ratio is much lower for the innovating than the noninnovating firms, and is no longer significant for the former. There is again evidence for diminishing returns for the innovating firms.

\section{Table 4: Sources of innovation outside the firm}

\begin{tabular}{clllll}
\hline Regression & $\mathbf{k} / \mathbf{l}$ & $\mathbf{L}$ & $\mathbf{S E C R D / Q _ { s }}$ & $\mathbf{S P I L L}_{\mathbf{2}}$ & $\mathbf{R}^{2}$ \\
\hline 1. All firms & $0.27 * * *$ & -0.08 & $1.00 * * *$ & & 0.36 \\
& $(0.06)$ & $(0.05)$ & $(0.20)$ & & \\
Innovators & 0.07 & $-0.17 * *$ & $0.65 * * *$ & & 0.31 \\
& $(0.09)$ & $(0.07)$ & $(0.24)$ & & \\
Non-innovators & $0.38 * * *$ & -0.04 & $1.44 * * *$ & & 0.45 \\
& $(0.08)$ & $(0.07)$ & $(0.33)$ & & \\
2. All firms & $0.27 * * *$ & -0.08 & $1.00 * * *$ & -0.27 & 0.36 \\
& $(0.06)$ & $(0.05)$ & $(0.20)$ & $(0.33)$ & \\
Innovators & 0.08 & $-0.17 * *$ & $0.64 * * *$ & -0.28 & 0.32 \\
& $(0.10)$ & $(0.07)$ & $(0.24)$ & $(0.30)$ & \\
Non-innovators & $0.38 * * *$ & -0.04 & $1.44 * * *$ & 0.47 & 0.45 \\
& $(0.09)$ & $(0.08)$ & $(0.33)$ & $(2.67)$ & \\
\hline
\end{tabular}

The sector $R \& D$ intensity variable itself has a very large effect on productivity growth, contributing around $1 \%$ of productivity growth for all firms. This result is consistent with other evidence, although variations in the 
innovation proxies used makes direct comparison of the size of coefficients difficult. Fecher (1990) found a strong role for what he termed 'indirect national R\&D expenditure': the R\&D expenditure of other firms in the same country, in the productivity growth of Belgium firms from 1981-1983. However, own R\&D expenditure and international indirect $R \& D$ expenditure had no significant relationship with productivity growth for the Belgium firms.

When the sample is split the magnitude of the effect of sector $R \& D$ varies over the two groups of firms, although both are significant. Sector R\&D intensity has a much greater impact on the non-innovating than the innovating firms. This is consistent with spillovers of innovations being of varying importance for firms with different characteristics. The $R \& D$ expenditure of other firms in the sector has a positive impact on non-innovating firms' productivity growth, while innovating firms rely more on their own resources. For the non-innovating firms, other firms' $R \& D$ increases their productivity by $1.44 \%$, indicating a high return for R\&D expenditure ${ }^{14}$.

The strong effects found for the R\&D intensity of other firms in the same sector, were not found for the $R \& D$ intensity of innovation-supplying industries. As Table Four shows, no significant effects were found for spillovers of R\&D from related sectors, and in two cases the coefficient was actually negative. The addition of the spillover variable does not improve the fit of the model at all. This result is in contrast to the Goto and Suzuki (1986) results for Japan ${ }^{15}$. The authors found that their technology flow matrix (consisting of the R\&D expenditure of supplying industries) had a much larger coefficient than each firm's own R\&D expenditure when estimating TFP growth. It appears that firms benefit from the R\&D undertaken by other firms in the same sector, but not from the R\&D undertaken in innovation-

\footnotetext{
${ }^{14}$ It is also possible that sector-level $R \& D$ is acting as a more effective proxy for $R \& D$ at the firm level than the firm level R\&D data used in this paper. As the discussion in Section Two pointed out, the balance-sheet $R \& D$ data almost certainly are a severe underestimate of real R\&D expenditure.

${ }^{15}$ The Goto and Suzuki (1989) technology-flow matrix was based on the purchase of inputs from different sectors rather than the use of innovations, it was thus reflecting different linkages in the economy and is not comparable to the one used here.
} 
supplying sectors. Geroski (1991) also found that the impact on the TFP growth of UK sectors of innovations both used and produced in neighbouring sectors was small in magnitude ${ }^{16}$. This lack of evidence for inter-industry spillovers largely refers to rent rather than knowledge spillovers, as the latter are not necessarily captured by considering the user-producer links in the economy. In order to investigate the importance of knowledge spillovers in the sample, alternative measures of spillovers need to be used (see for instance Wolff and Nadiri, 1993). Los and Verspagen (1997) included a number of different proxies for indirect R\&D stocks in their panel-data study for US firms. In general they found knowledge spillovers to be a more important source of productivity growth than rent spillovers.

In order to investigate the relationship between $R \& D$ intensity and productivity growth across different sectors a division of firms into different groups is adopted. This allows the coefficient on the R\&D intensity variable to vary by group, indicating a different marginal contribution to productivity growth for different groups. As there is only a limited number of firms in some sectors, giving small degrees of freedom, the sector division used earlier is not applied. Instead, the firms are separated into two groups based on the characteristics of the sector in which they are located: net users of innovations i.e. sectors that use more innovations than they produce, and net producers of innovations, sectors which produce more innovations than they use ${ }^{17}$.

This separation is based on information on innovation taken from the SPRU survey. As the use and production of innovations at a sector level are very stable over time the delay between the survey data and the sample used here is not a problem ${ }^{18}$. This classification based on the net production of innovations is preferred to the more frequently used one based on the

\footnotetext{
${ }^{16}$ However, other studies such as Jaffe (1986) find evidence for a strong role for spillovers defined in a different way.

17 The 18 sector classification is used to give more detail. Some of the sectors are large producers of innovations which are used in many other sectors; they include: chemicals, mechanical engineering, instruments and electrical and electronic machinery. See Robson et al. (1987) for more details.

${ }^{18}$ A correlation between the ratio for the whole period 1956-1983 and for the last five years is very high indeed.
} 
technological level of the sector according to its $R \& D$ level ${ }^{19}$. The separation used in this paper captures one of the most interesting sector characteristics, and one which has considerable implications for the economy as a whole the ability of the sector to generate innovations which are subsequently used in other sectors. As the data collected from this survey have already shown (Pavitt, 1984, Robson et al., 1987)) some sectors in the economy produce a high proportion of the innovations used in the economy as a whole, and as a result play an important role in the diffusion of innovation and hence economic growth. By using only two broadly-defined groups of firms a high degree of freedom is also maintained. The results using this separation are reported in Table Five; the three different regressions are repeated for each group of sectors.

\section{Table 5: Dividing the sample by sector}

\begin{tabular}{|c|c|c|c|c|}
\hline Regression & $\mathrm{k} / \mathrm{l}$ & $\mathbf{L}$ & $\mathbf{R D} / \mathbf{Q}$ & $\mathbf{R}^{2}$ \\
\hline \multicolumn{5}{|c|}{ Net producers of innovations } \\
\hline 1. & $\begin{array}{l}0.22 * * * \\
(0.07)\end{array}$ & & & 0.12 \\
\hline 2. & $\begin{array}{l}0.23 * * * \\
(0.07)\end{array}$ & & $\begin{array}{l}0.21 \\
(0.26)\end{array}$ & 0.13 \\
\hline 3. & $\begin{array}{l}0.17 * * \\
(0.09)\end{array}$ & $\begin{array}{l}-0.10 \\
(0.07) \\
\end{array}$ & $\begin{array}{l}0.16 \\
(0.27)\end{array}$ & 0.15 \\
\hline \multicolumn{5}{|c|}{ Net users of innovations } \\
\hline 1. & $\begin{array}{l}0.54 \text { *** } \\
(0.12)\end{array}$ & & & 0.35 \\
\hline 2. & $\begin{array}{l}0.52 * * * \\
(0.12)\end{array}$ & & $\begin{array}{l}0.50 * \\
(0.29)\end{array}$ & 0.40 \\
\hline 3. & $\begin{array}{l}0.44 * * * \\
(0.12)\end{array}$ & $\begin{array}{l}-0.26 \text { ** } \\
(0.10)\end{array}$ & $\begin{array}{l}0.56 * * \\
(0.27)\end{array}$ & 0.51 \\
\hline
\end{tabular}

The results are similar to those found for the innovating and non-innovating firms, although they diverge in some ways. The capital to labour ratio has a much higher coefficient for the innovation-using sectors than the innovationproducing sectors. One of the contrasts of the results is that diminishing returns are found for firms in the innovation-using sectors. Similar results

19 Odagiri and Iwata (1986) make estimates based on a separation into innovating and non-innovating sectors using on R\&D intensity; Griliches and Mairesse (1984) separate firms into 'scientific' firms and 'other' firms 
were found for the innovating firms (Table Three), which we would expect to be more frequently located in the innovation-producing sectors. Constant returns to scale are not rejected for the producing sectors. The results are in contrast to those of Griliches and Mairesse (1984) who found that R\&D expenditure had a positive and significant effect on productivity growth only for firms in 'scientific' sectors. For firms based in other sectors the relationship was negative and insignificant.

That R\&D intensity is significantly related to productivity growth only for firms in the innovation-using sectors may be partly explained by the hypothesis put forward by Cohen and Levinthal, (1989). They suggested that firms may need some $R \& D$ capabilities in order to benefit from the innovations of other firms; to improve what they describe as a firm's 'absorbative capacity'. However, the result is perplexing as the innovationproducing sectors do not appear to benefit from their own R\&D expenditure. This may be due to weaknesses in the $R \& D$ expenditure variable, which make it an inadequate proxy for technology. The results here indicate that for firms located in sectors which are net users of innovations, R\&D intensity has a much greater impact on productivity growth than for firms located in net producing sectors. For the latter the relationship is not even significant. The model is able to explain a higher percentage of the growth in productivity for using rather than producing sectors, indicating that there may be important other factors to consider for the latter which are not included in the model.

The results confirm that the relationship between $R \& D$ intensity and productivity growth varies considerably across firms with different characteristics (innovating, non-innovating) and sectors with different innovation histories. Sterlacchini (1989) found similar results on a sector level for the UK using the SPRU survey data but for an earlier period. For the period before 1973 the author found that the use of $R \& D$ activities (R\&D of other sectors weighted from the SPRU survey as in this paper) explained inter-industry differences in TFP growth better than R\&D expenditure.

also based on R\&D intensity. 
However, the author found no significant relationship between R\&D intensity and TFP growth in the 1980s.

Overall the results do not indicate a stable relationship between R\&D intensity and productivity growth for all firms in the sample. Although a significant positive relationship between the two is found, when sector fixed effects are included this relationship is no longer significant. The R\&D intensity of other firms in the same sector, however, appears to have a large and significant effect on firm productivity growth. There is no evidence to support the existence of spillovers of $R \& D$ from innovation-supplying sectors. The final division into sectors - net producing and net using sectors shows a positive relationship only for using sectors.

\section{Conclusions}

The results presented in this paper indicate that the role of $R \& D$ expenditure in productivity growth in the UK is similar to that found for other countries such as the US, France and Japan for this sample of quoted firms. However, the relationship between productivity growth and $R \& D$ intensity was also found to be very sensitive to the inclusion of sector dummy variables, indicating an important role for different sector conditions in explaining variations in productivity growth. The inclusion of the $R \& D$ expenditure of other firms in the same sector improves the results; inter-sector variations in the level of technological opportunity appear to be important in altering the efficacy of R\&D expenditure.

While the R\&D of other firms in the same sector seems to play a significant role in productivity growth, no role was found for spillovers of R\&D expenditure from innovation-supplying sectors. This is in contrast to many microeconomic studies which have found evidence of important inter-sector spillovers of innovation. This result may be due of the measurement of spillovers used: the use of the production and use of innovation matrix captures only a certain type of relationship between sectors reflecting mainly rent spillovers. The matrix represents only the flow of major innovations to 
the first user, rather than incremental and small innovations and the greater diffusion of innovations across sectors.

As there is considerable heterogeneity among firms, attempts were also made to group the firms according to their innovation histories. Innovative firms spent more on $\mathrm{R} \& \mathrm{D}$ expenditure relative to sales than non-innovating firms (2.3\% against $0.8 \%$ in the period 1988 to 1992 ); however, this $R \& D$ expenditure appeared to contribute less to their productivity growth than the lower R\&D expenditure of non-innovating firms. The low fecundity of innovating firms' $\mathrm{R} \& \mathrm{D}$ expenditure indicates the potential importance of spillovers of innovation. The high fecundity of non-innovating firms' $R \& D$ expenditure implies in turn that their R\&D expenditure allows them to exploit more than just their own innovation potential, but possibly gives them access to spillovers of innovation. As this effect is significantly reduced with the inclusion of dummy variables, the level of technological opportunity in the sector appears to partly explain this phenomenon.

Overall the results confirm a positive role for $R \& D$ expenditure in productivity growth, although the exact nature of the relationship is unclear. It appears to be difficult to disentangle the impact of R\&D expenditure at the firm-level from that at the sector-level. Further investigation into the interrelationships among firm $R \& D$, sector $R \& D$ and inter-sector spillovers is clearly required. The framework applied here appears to be particularly ineffective in explaining the productivity growth of innovative firms. Innovative firms may have internal resources which mark them out from other firms and explain their better productivity history and ability to innovate over time. 


\section{Appendix: Data definition and sources}

Real capital: total fixed gross assets from Datastream deflated by the investment deflator from the 1996 UK National Accounts.

Real total sales: total sales taken from Datastream deflated by the producer price output index taken from the UK Monthly Digest of Statistics (1993).

R\&D expenditure taken from Datastream.

Sector R\&D expenditure came from First Release, CSO Number 188, December 1993 'Business Enterprise Research and Development 1992'.

Sector level output came from the CSO Report on the Census of Production 1991 Summary Volume PA 1002 from Business Monitor.

Data on innovations come from 'Innovations in the UK since 1945' Science Policy Research Unit, University of Sussex; data obtained from the ESRC archive, Essex.

The number of employees was taken from Datastream.

The sector classification used is given below for 18 sectors. The 2-digit 1980 revised SIC classification is given after the name of the sector. When a 10 sector division was used sectors 1 (metal manufacturing) and 4 (other metal goods) were included together as where the two transport sectors 8 and 9. All the sectors from 11 to16 were included as one sector; sectors 17 and 18 were also grouped together.

\section{The Sector Classification}

1 metal manufacturing (22)

2 non-metallic manufacturing (24)

3 chemical \& man-made products ( $25 \& 26)$

4 other metal goods (31)

5 mechanical engineering (32)

6 office and data machinery (33)

7 electrical \& electronic machinery (34)

8 motor vehicles \& parts (35)

9 other transport (36)
10 instrument engineering (37)

11 food, drink \& tobacco (41/42)

12 textiles (43)

13 leather goods (44)

14 footwear \& clothing (45)

15 timber (46)

16 paper \& printing (47)

17 rubber \& plastics (48)

18 other manufacturing (49) 


\section{References}

Cohen, Wesley M. \& Daniel A. Levinthal (1989) Innovation and Learning: The Two Faces of R\&D, The Economic Journal, 99, pp. 569-596.

Cuneo, P. and J. Mairesse (1984) Productivity and R\&D at the Firm Level in French Manufacturing, in Z. Griliches, (ed), $R \& D$, Patents and Productivity, University of Chicago Press: Chicago.

Fecher, F. (1990) Effects Directs et Indirects de la R\&D sur la Productivité: une analyse de l'Industrie Manufacturière Belge, Cahiers Économiques de Bruxelles, 0 (128), pp. 459-83.

Geroski, P.A. (1991) Innovation and the Sectoral Sources of UK Productivity Growth, The Economic Journal, 101, pp. 1438-51.

Goto, A. and K. Suzuki (1989) R\&D Capital, Rate of Return on R\&D Investment and Spillover of R\&D in Japanese Manufacturing, Review of Economics and Statistics, 71, pp. 555-564.

Griliches, Z. (1979) Issues in Assessing the Contribution of Research and Development to Productivity Growth, The Bell Journal of Economics, 10, pp. 92-116.

Griliches, Z. (1986) Productivity, R\&D and Basic Research at the Firm Level in the 1970s, American Economic Review, 76, pp. 141-54.

Griliches, Z. (1992) The Search for R\&D Spillovers, Scandinavian Journal of Economics, 94, pp. S29-S47.

Griliches, Z. and J. Mairesse (1983) Comparing Productivity growth: An Exploration of French and US Industrial and Firm Data, European Economic Review, 21, pp. 89-119.

Griliches, Z. and J. Mairesse (1984) Productivity and R\&D at the Firm Level, in Z. Griliches (ed), $R \& D$, Patents and Productivity, University of Chicago Press: Chicago.

Griliches, Z. and J. Mairesse, (1990) R\&D and Productivity Growth: Comparing Japanese and US Manufacturing Firms, in C. Hulten (ed), 
Productivity Growth in Japan and the United States, University of Chicago Press: Chicago.

Grossman, G. \& E. Helpman (1991) Innovation and Growth, Technological Competition in the Global Economy, MIT Press: Cambridge Ma.

Jaffe, A. (1986) Technological Opportunity and Spillovers of R\&D, American Economic Review, 76, pp. 984-1001.

Lansbury, M. and D. Mayes (1996) Productivity Growth in the 1980s, in D. Mayes (ed) Sources of Productivity Growth, Cambridge University Press: Cambridge.

Lichtenberg, Frank R. and Donald Siegel (1991) The Impact of R\&D Investment on Productivity New Evidence Using Linked R\&D - LRD Data, Journal of Economic Inquiry, 29, pp. 203-29.

Los, Bart (1997) A Review of Interindustry Technology Spillover Measurement Methods, University of Twente, Mimeo.

Los, Bart and Bart Verspagen (1997) R\&D Spillovers and Productivity: Evidence from U.S. Manufacturing Microdata, MERIT Working Paper 2/97-007, Maastricht.

Malerba, Franco, Luigi Orsenigo and Pietro Peretto (1997) Persistence in Innovative Activities, Sectoral Patterns of Innovation and International Technological Specialisation, International Journal of Industrial Organisation, 15, pp. 801-26.

Mairesse, J. and P. Cuneo (1985) Rechereche-développement et performances des entreprises: une étude économétrique sur donées individuelles, Revue Economique, 36, pp. 1001-42.

Mairesse, J. and M. Sassenou (1991) R\&D and Productivity: A Survey of Econometric Studies at the Firm Level, The Science Technology and Industry Review, 8, pp. 317-48.

Nadiri, M.I. (1993) Innovations and Technological Spillovers, NBER Working Paper \# 4423. 
Odagiri, H. and H. Iwata (1986), The Impact of R\&D on Productivity Increase in Japanese Manufacturing Companies, Research Policy, 15, pp. 13-19.

Pavitt, K. (1984) Sectoral Patterns of Technical Change; Towards a Taxonomy and a Theory, Research Policy, 13(6), pp. 343-73.

Pavitt, K., M. Robson \& J. Townsend (1987), The Size Distribution of Innovating Firms in the UK: 1945-1983, Journal of Industrial Economics, Volume XXXV.

Robson, M., J. Townsend and K. Pavitt (1987) Sectoral Patterns of Production and Use of Innovations in the UK: 1945-1983, Research Policy, 17, pp. 1-14.

Romer, P. (1986) Increasing Returns and Long-Run Growth, Journal of Political Economy, 94, pp. 1002-37.

Scherer, F.M. (1982) Inter-Industry technology flows and productivity growth, Review of Economics and Statistics, 64, pp. 627-634.

Solow, R.M. (1957) Technical Progress and the Aggregate Productiono Function, Review of Economics and Statistics, 39, pp. 312-320.

Sterlacchini, A. (1989) R\&D, Innovations and Total Factor Productivity Growth in British Manufacturing, Applied Economics, 21, pp. 1549-62.

Wakelin, K. (1997) Trade and Innovation: Theory and Evidence, Edward Elgar: Aldershot, forthcoming.

Wolff, E.N. and M.I. Nadiri (1993) Spillover Effects, Linkage Structure and Research and Development, Structural Change and Economic Dynamics, 4, pp. 315-31. 